\title{
КІЛЬКІСНИЙ МОРФОЛОГІЧНИЙ АНАЛІЗ ОСОБЛИВОСТЕЙ РЕМОДЕЛЮВАННЯ ГЕМОМІКРОЦИРКУЛЯТОРНОГО РУСЛА СІМ'ЯНИКІВ ПРИ ДІЇ НА ОРГАНІЗМ КАДМІЮ ХЛОРИДУ
}

\author{
๑М. С. Гнатюк, С. О. Коноваленко, Л. В. Татарчук
}

Тернопільський начіональний медичний університет імені І. Я. Горбачевського МОЗ України

РЕЗЮМЕ. Сучасні дослідники вказують на негативний вплив шкідливих факторів довкілля на генеративну функцію у чоловіків. Функціонально-структурні зміни гемомікроциркуляторного русла, яке першим реагує на шкідливі фактори екзогенного походження, у сім'яниках вивчені недостатньо.

Мета - провести морфометричний аналіз особливостей ремоделювання судин гемомікроциркуляторного русла сім'яників при дії на організм кадмію хлориду.

Матеріал і методи. Морфологічно вивчені сім'яники 60 білих щурів-самців, які були поділені на дві групи. 1-а група включала 30 інтактних тварин, 2-а - 30 щурів, яким підшкірно вводили хлорид кадмію в дозі 6 мг/кг впродовж 4-х тижнів. Евтаназію тварин здійснювали кровопусканням в умовах тіопенталового наркозу через місяць від початку експерименту. Гемомікроциркуляторне русло сім'яників вивчали за допомогою наповнення їх судин туш-желатиновою сумішшю, яку вводили через черевну аорту. Із сім'яників виготовляли просвітлені та гістологічні препарати, забарвлені гематоксиліном-еозином. Морфометрично визначали діаметри артеріол, передкапілярних артеріол, гемокапілярів, закапілярних венул, венул та щільність мікросудин лівого та правого сім'яників. Кількісні показники обробляли статистично.

Результати. Тривала дія на організм кадмію хлориду призводила до виражених змін кількісних морфологічних показників судин гемомікроциркуляторного русла сім'яників експериментальних тварин, порівняно з контрольними. Діаметр артеріол лівого сім'яника у змодельованих експериментальних умовах зменшився на 19,2 \% $(p<0,001)$, передкапілярних артеріол - на 23,3% ( $<<0,001)$ гемокапілярів - на 16,7 \% ( $<<0,001)$. Діаметр закапілярних венул лівого сім'яника при цьому збільшився на 32,7 \%, венул - на 28,3 \% ( $<<0,001)$, а щільність мікросудин зменшилася на 30,0 \% (p<0,001), що свідчить про погіршання його кровопостачання.

Ступінь ремоделювання мікросудин у правому сім'янику виявився менш вираженим. Діаметр артеріол правого сім'яника зменшився на 18,2 \%, передкапілярних артеріол - на 22,6 \%, а гемокапілярів - на 15,8 \% (p<0,001). Діаметр закапілярних венул правого сім'яника при цьому збільшився на 31,5 \%, венул - на 27,8 \% (p<0,001), а щільність мікросудин зменшилася на 27,1 \% (р<0,001). Світлооптично морфологічні зміни структур домінували у лівому сім'янику.

Висновок. Тривала дія на організм кадмію хлориду призводить до вираженого ремоделювання судин гемомікроциркуляторного русла сім'яників, яке характеризується вираженим звуженням його приносної (артеріол, передкапілярних артеріол), обмінної (гемокапілярів) ланок та розширенням закапілярних венул і венул, венозним повнокрів'ям, гіпоксією, дистрофічними, некробіотичними змінами клітин і тканин, інфільтративними та склеротичними процесами, які домінують у лівому сім'янику.

КЛючОВІ СлОВА: сім'яники, гемомікроциркуляторне русло, морфометрія, кадмію хлорид.

Вступ. Сьогодні спостерігається зростання техногенного навантаження на довкілля, в результаті чого в ньому зростає кількість хімічних речовин та їхніх метаболітів, які можуть негативно впливати на органи і системи організму та погіршувати перебіг різних патологій. Особливо шкідливими для живих організмів $\epsilon$ солі важких металів, до яких належить кадмію хлорид [6]. Репродуктивна система у чоловіків при цьому може ускладнитися азооспермією (відсутність сперматозоїдів в еякуляті) [2]. Останніми десятиріччями показники репродуктивного і сексуального здоров'я чоловіків знижуються у багатьох країнах світу, але в Україні вони мають стрімку вкрай негативну тенденцію $[2,5,7]$. Сучасні дослідники підкреслюють недооцінювання негативного впливу факторів довкілля на генеративну функцію у чоловіків.
Судини гемомікроциркуляторного русла, де проходить транскапілярний обмін, відіграють важливу роль у трофічному забезпеченні клітин та тканин і у патоморфогенезі їх ушкоджень. Варто вказати, що особливості ремоделювання гемомікроциркуляторного русла сім'яників при дії на організм кадмію хлориду досліджені недостатньо. Відомо також, що функціонально-структурні зміни у судинах гемомікроциркуляторного русла $\epsilon$ першими ранніми ознаками при впливах на організм негативних факторів ендогенного та екзогенного походження [3].

Мета - провести морфометричний аналіз особливостей ремоделювання судин гемомікроциркуляторного русла сім'яників при дії на організм кадмію хлориду.

Матеріал і методи дослідження. Комплексом морфологічних методів вивчені сім'яники 
Огляди літератури, оригінальні дослідження, погляд на проблему, випадок з практики, короткі повідомлення 60 статевозрілих білих щурів-самців, які були поділені на дві групи. 1-а група (контрольна) включала 30 тварин, які перебували у звичайних умовах віварію, 2-а - 30 щурів, яким підшкірно вводили хлорид кадмію в дозі 6 мг/кг впродовж 4-х тижнів [7]. Евтаназію дослідних тварин здійснювали кровопусканням в умовах тіопенталового наркозу через місяць від початку експерименту.

Гемомікроциркуляторне русло сім'яників вивчали за допомогою наповнення їх судин тушжелатиновою сумішшю, яку вводили через черевну аорту. Через 3-4 години після заповнення кровоносного русла сім'яників вказаною сумішшю проводили їх забір і фіксували в 10 \% розчині нейтрального формаліну впродовж 2 тижнів. На заморожуючому мікротомі виготовляли зрізи товщиною 30-40 мкм, які зневоднювали в етилових спиртах зростаючої концентрації, просвітлювали у метиловому ефірі саліцилової кислоти і поміщали у полістирол. Виготовлені за вказаною методикою мікропрепарати досліджували за допомогою бінокулярного мікроскопа МБР-3, МБД-15 при різних збільшеннях. Із частини сім'яників із заповненими туш-желатиновою сумішшю судинами виготовляли також гістологічні препарати, забарвлені

гематоксиліном-еозином [4]. Морфометрично визначали діаметри артеріол (ДА), передкапілярних артеріол (ДПА), гемокапілярів (ДГ), закапілярних венул (ДЗВ), венул (ДВ) та щільність мікросудин

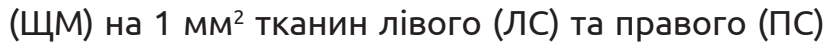
сім'яників $[1,3]$. Кількісні показники обробляли статистично. Обробка отриманих результатів виконана у відділі системних статистичних досліджень Тернопільського національного медичного університету імені І. Я. Горбачевського МОЗ України в програмному пакеті Statistica. Різницю між порівнюваними величинами визначали за критеріями Стьюдента та Манна-Уїтні [8]. Проведення експериментів та евтаназію дослідних тварин виконували 3 дотриманням «Загальних етичних принципів експериментів на тваринах», ухвалених Першим національним конгресом з біоетики (Київ, 2001), відповідно до «Європейської конвенції про захист хребетних тварин, що використовуються у дослідних та інших наукових цілях», а також Закону України «Про захист тварин від жорстокого поводження» (від 21.02.2006) [9].

Результати й обговорення. Отримані результати проведеного дослідження представлено в таблиці 1.

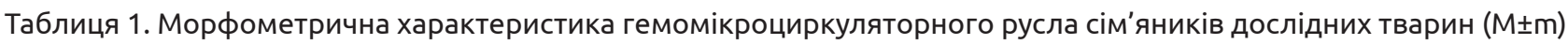

\begin{tabular}{|l|c|c|}
\hline \multirow{2}{*}{ Показник } & \multicolumn{2}{|c|}{ Група тварин } \\
\cline { 2 - 3 } & перша & друга \\
\hline ДДАЛС, мКм & $18,20 \pm 0,30$ & $14,70 \pm 0,27^{* * *}$ \\
\hline ДПАЛС, МКм & $10,82 \pm 0,12$ & $8,30 \pm 0,12^{* * *}$ \\
\hline ДГЛС, МКм & $6,12 \pm 0,09$ & $5,10 \pm 0,09^{* * *}$ \\
\hline ДЗВЛС, мКм & $12,58 \pm 0,15$ & $16,70 \pm 0,15^{* * *}$ \\
\hline ДВЛС, мКм & $26,57 \pm 0,30$ & $34,10 \pm 0,33^{* * *}$ \\
\hline ЩЛС & $843,3 \pm 28,2$ & $2690,5 \pm 23,1^{* * *}$ \\
\hline ДАПС, мКм & $18,22 \pm 0,30$ & $14,90 \pm 0,30^{* * *}$ \\
\hline ДПАПС, МКм & $10,85 \pm 0,12$ & $8,40 \pm 0,12^{* * *}$ \\
\hline ДГПС, мКм & $6,12 \pm 0,09$ & $5,15 \pm 0,06^{* * *}$ \\
\hline ДЗВПС, мКм & $12,54 \pm 0,15$ & $16,50 \pm 0,12^{* * *}$ \\
\hline ДВПС, мКм & $26,53 \pm 0,30$ & $33,90 \pm 0,33^{* * *}$ \\
\hline ЩМС & $3836,8 \pm 30,3$ & $2794,7 \pm 24,2^{* * *}$ \\
\hline
\end{tabular}

Примітка. ***-p<0,001.

У результаті всестороннього аналізу даних вказаної таблиці встановлено, що тривала дія на організм кадмію хлориду призводила до виражених змін кількісних морфологічних показників судин гемомікроциркуляторного русла, порівняно 3 контрольними. Так, діаметр артеріол лівого сім'яника у змодельованих експериментальних умовах з вираженою статистично достовірною різницею $(p<0,001)$ зменшився з $(18,20 \pm 0,30)$ мкм до $(14,70 \pm$ $0,27)$ мкм, тобто на $19,2 \%$. Аналогічно змінювався також діаметр передкапілярних артеріол вказано- го сім'яника. Так, діаметр передкапілярних артеріол неушкодженого лівого сім'яника дорівнював $(10,82 \pm 0,12)$ мкм, а в разі ушкодження кадмію хлоридом - $(8,30 \pm 0,12)$ мкм. Наведені морфометричні параметри статистично достовірно $(p<0,001)$ відрізнялися між собою. При цьому останній кількісний морфологічний показник виявився меншим за аналогічний контрольний на 23,3\%. Просвіти гемокапілярів у досліджуваних умовах експерименту також з високим ступенем статистично достовірної різниці $(p<0,001)$ зменшилися на $16,7 \%$. 
Огляди літератури, оригінальні дослідження, поглядн на

У результаті кількісного морфологічного аналізу встановлено, що венозні судини гемомікроциркуляторного русла лівого сім'яника при дії на організм дослідних тварин кадмію хлориду розширювалися. Так, у змодельованих експериментальних умовах діаметр закапілярних венул лівого сім'яника статистично достовірно ( $p<0,001)$ збільшився на 32,7 \%, а венул - на 28,3\% ( $<<0,001)$. Щільність мікросудин при цьому на одиниці площі тканин досліджуваного органа виражено зменшилася майже на 30,0 \% ( $<<0,001)$, що свідчило про погіршання його кровопостачання $[3,5]$.

Структурна перебудова судин гемомікроциркуляторного русла правого сім'яника при дії на організм дослідних тварин кадмію хлориду виявилася аналогічною вищеописаній. Варто зазначити, що в результаті аналізу досліджуваних морфометричних параметрів встановлено, що ступінь ремоделювання мікросудин гемомікроциркуляторного русла у лівому та правому сім'яниках виявився неоднаковим. Так, діаметр артеріол правого сім'яника у змодельованих умовах експерименту $з$ вираженою статистично достовірною різницею ( $p<0,001)$ зменшився на $18,2 \%$, порівняно з аналогічним контрольним показником, діаметр передкапілярних артеріол - на 22,6\% (р<0,001), а гемокапілярів - на 15,8 \% (р<0,001). Виносні судини гемомікроциркуляторного русла (закапілярні венули та венули) під впливом кадмію хлориду розширювалися. Так, діаметр закапілярних венул правого сім'яника при цьому з високим ступенем статистично достовірної різниці $(p<0,001)$ збільшився на $31,5 \%$, а венул - на 27,8 \% (p<0,001). Щільність мікросудин у цих експериментальних умовах зменшилася з $(3836,8 \pm 30,3)$ до $(2794,7 \pm 24,2)$, тобто на $27,1 \%(p<0,001)$.

Гістологічно виявлене розширення переважно венозних судин сім'яників, особливо закапілярних венул та венул, які розширені, переповнені кров'ю, з осередками стазів, тромбозів, діапедезних, паравазальних крововиливів. Виражене венозне повнокров'я ускладнювалося гіпоксією, яка призводила до дистрофічних та некробіотичних змін ендотеліоцитів, міоцитів судин, сперматогенних епітеліоцитів, стромальних структур, інфільтрації та склерозу. Структурні зміни домінували у лівому сім'янику, що пов'язано з особливостями венозного відтоку $[3,5]$.

Висновок. Тривала дія на організм кадмію хлориду призводить до вираженого ремоделювання судин гемомікроциркуляторного русла сім'яників, яке характеризується вираженим звуженням його приносної (артеріол, передкапілярних артеріол), обмінної (гемокапілярів) ланок та розширенням закапілярних венул і венул, венозним повнокрів'ям, гіпоксією, дистрофічними, некробіотичними змінами клітин і тканин, інфільтративними та склеротичними процесами, які домінують у лівому сім'янику.

Перспективи подальших досліджень. Детальне усестороннє вивчення досліджених явищ та процесів представляє перспективну проблему з метою їхнього врахування при діагностиці, корекції та профілактиці уражень сім'яників хімічними речовинами.

\section{ЛІТЕРАТУРА}

1. Автандилов Г. Г. Основы количественной патологической анатомии / Г. Г. Автандилов. - М. : Медицина, 2002. -240 c.

2. Базалицька С. В. Чоловіча неплідність в Україні: особливості пато- і морфогенезу / С. В. Базалицька. К. : ТОВ «Четверта хвиля", 2016. - 262 с.

3. Гнатюк М. С. Особливості ремоделювання судин гемомікроциркуляторного русла яєчок при пострезекційній портальній гіпертензії / М. С. Гнатюк, С. О. Коноваленко, Л. В. Татарчук // Шпитальна хірургія. - 2019. Вип. 4. - С. 37-42.

4. Горальський Л. П. Основи гістологічної техніки і морфофункціональні методи досліджень у нормі та при патології / Л. П. Горальський, В. Т. Хомич, О. І. Кононський. - Житомир : Полісся, 2011. - 288 с.

5. Долинко Н. П. Влияние гинкго билоба на морфометрические и функциональные показатели спермато-

зоидов в условиях хронической этаноловой интоксикации / Н. П. Долинко // Вестнік Могілеускага дзяржаунага універсітэта імя А. А. Куляшова. Серыя Прыроданаучия наукі. - 2015. - № 2 (46). - С. 99-102.

6. Дубініна А. А. Токсичні речовини і методи їх визначення / А. А. Дубініна. - Харків : ХДУХТ, 2016. - 106 с.

7. Коноваленко С. О. Структурні зміни в яєчку при дії на організм хлориду кадмію / С. О. Коноваленко, В. В. Лотоцький, Л. В. Татарчук // Проблеми військової охорони здоров'я. - 2016. - № 45. - Р. 199-206.

8. Лапач С. Н. Статистические методы в медикобиологических исследованиях Excell / С. Н. Лапач, А. В. Губенко, П. Н. Бабич. - К. : Морион, 2001. - 410 с.

9. Резніков О. Г. Загальні етичні принципи експериментів на тваринах / О. Г. Резніков // Ендокринологія. 2003. - T. 8, № 1. - C. 142-145. 
Огляди літератури, оригінальні дослідження, погляд на проблему, випадок з практики, короткі повідомлення REFERENCES

1. Avtandilov, G.G. (2002). Osnovy kolichestvennoy patologicheskoy anatomii [Basis of quantative pathological anatomy]. Moscow: Meditsyna [in Russian].

2. Bazalytska, S.V. (2016). Cholovicha neplidnist $v$ Ukraini: osoblyvosti pato- $i$ morphohenezu [Male infertility in Ukraine: features of pathogenesis and morphogenesis]. Kyiv: TOV "Chetverta khvylia" [in Ukrainian].

3. Hnatyuk, M.S., Konovalenko, S.O., \& Tatarchuk, L.V. (2019). Osoblyvosti remodeliuvannia sudyn hemomikrotsyrkuliatornoho rusla yaiechok pry postrezektsiinii portalnii hipertenzii [Peculiarities of vascular remodeling of hematomicrocirculatory bad at post-resection portal hypertension]. Shpytalna khirurhiya - Hospital Surgery, 4, 3742 [in Ukranian].

4. Goralsky, L.P., Khomich, V.T., \& Kononsky, O.I. (2011). Osnovy histolohichnoi tekhniky i morfofunktsionalni metody doslidzhen u normi i pry patolohii [Fundamentals of histological technique and morphofunctional methods of research in normal and pathology]. Zhytomyr: Polissia [in Ukrainian].

5. Dolynko, N.P. (2015). Vliyaniie ginko biloba na morfometricheskiye i funktsionalnye pokazateli spermatozoidov $v$ usloviyakh khronicheskoy etanolovoy intoksika-

tsii [The influence of ginkgo biloba on the morphometric and functional indicator of spermatozoa in conditions of chronic ethanol intoxication].Vestnik Mogelevskoho derzhavnoho universytetu im. A.A. Kuliashova. Seriia Pryrodnychi nauky - Bulletin of Mogilev State University by A.A. Kuleshov. Natural Science Series, 2 (46), 99-102 [in Russian].

6. Dubinina, A.A. (2016). Toksychni rechovyny i metody yikh vyznachennia [Toxic substances and methods for their determination]. Kharkiv: KHDUKHT [in Ukrainian].

7. Konovalenko, S.O., Lototskyi, V.V., \& Tatarchuk, L.V. (2016) Strukturni zminy $v$ yaiechku pry dii na orhanism khlorydu kadmiiu [Structural changes in the testis when exposed to cadmium chloride]. Problemy viiskovoi okhorony zdorovia - Problems of Military Health Care, 45, 199-206 [in Ukranian].

8. Lapach, S.N., Gubenko, A.V., \& Babych, P.N. (2001). Statisticheskye metody $v$ mediko-biologicheskykh issledovanyiakh Excell [Statistical methods in biomedical research Excell]. Kyiv: Morion [in Russian].

9. Reznykov, O.H. (2003). Zahalni etychni pryntsypy eksperymentiv na tvarynakh [General ethical principles experiments on animals]. Endokrynolohiia - Endocrinology, 8, 1, 142-145 [in Ukrainian].

\title{
КОЛИЧЕСТВЕННЫЙ МОРФОЛОГИЧЕСКИЙ АНАЛИЗ ОСОБЕННОСТЕЙ РЕМОДЕЛИРОВАНИЯ ГЕМОМИКРОЦИРКУЛЯТОРНОГО РУСЛА СЕМЕННИКОВ ПРИ ДЕЙСТВИИ НА ОРГАНИЗМ КАДМИЯ ХЛОРИДА
}

\author{
ФМ. С. Гнатюк, С. О. Коноваленко, Л. В. Татарчук
}

Тернопольский национальный медицинский университет имени И. Я. Горбачевского Моз Украины

РЕЗЮМЕ. Современные исследователи указывают на негативное влияние вредных факторов окружающей среды на генеративную функцию у мужчин. Функционально-структурные изменения гемомикроциркуляторного русла, которое первым реагирует на вредные факторы экзогенного происхождения, в семенниках изучены недостаточно.

Цель - провести морфометрический анализ особенностей ремоделирования сосудов гемомикроциркуляторного русла семенников при воздействии на организм кадмия хлорида.

Материал и методы. Морфологически изучены семенники 60 белых крыс-самцов, которые были поделены на две группы. Первая группа включала 30 интактных животных, вторая - 30 крыс, которым подкожно вводили хлорид кадмия в дозе 6 мг/кг в течение 4-х недель. Эвтаназию животных осуществляли кровопусканием в условиях тиопенталового наркоза через месяц от начала эксперимента. Гемомикроциркуляторное русло семенников изучалось с помощью наполнения их сосудов тушь-желатиновой смесью, которую вводили через брюшную аорту. Из семенников изготавливали просветленные и гистологические препараты, окрашенные гематоксилиномэозином. Морфометрически определяли диаметры артериол, передкапиллярных артериол, гемокапилляров, посткапиллярних венул, венул и плотность микрососудов левого и правого семенников. Количественные показатели обрабатывали статистически.

Результаты. Длительное воздействие на организм кадмия хлорида приводило к выраженным изменениям количественных морфологических показателей сосудов гемомикроциркуляторного русла семенников по сравнению с контрольными. Диаметр артериол левого семенника в смоделированных экспериментальных условиях уменьшился на 19,2 \% (р<0,001), передкапиллярных артериол - на 23,3 \% (p<0,001), гемокапилляров - на 16,7 \% ( $<<0,001)$. Диаметр посткапиллярних венул левого семенника при этом увеличился на $32,7 \%$, венул - на 28,3 \% ( $<<0,001)$, а плотность микрососудов уменьшилась на 30,0\% ( $<<0,001)$, что свидетельствовало об ухудшении его кровоснабжения.

Степень ремоделирования микрососудов в правом семеннике оказалась менее выраженной. Диаметр артериол правого семенника уменьшился на 18,2 \%, передкапиллярных артериол - на 22,6 \%, а гемокапилляров - на 15,8 \% (р<0,001). Диаметр посткапиллярних венул правого семенника при этом увеличился на 31,5 \%, венул - на 
Огляди літератури, оригінальні дослідження, погляд на проблему, випадок з практики, короткі повідомлення $27,8$ \% ( $<<0,001)$, а плотность микрососудов уменьшилась на 27,1 \% ( $<<0,001)$. Светооптически морфологические изменения структур доминировали в левом семеннике.

Вывод. Длительное воздействие на организм кадмия хлорида приводит к выраженному ремоделированию сосудов гемомикроциркуляторного русла семенников, характеризующемуся выраженным сужением его приносящих (артериол, передкапиллярных артериол), обменных (гемокапилляров) звеньев и расширением посткапиллярых венул и венул, венозным полнокровием, гипоксией, дистрофическими, некробиотическими изменениями клеток и тканей, инфильтративными и склеротическими процессами, которые доминировали в левом семеннике.

КЛючЕВЫЕ СЛОВА: семенники; гемомикроциркуляторное русло; морфометрия; кадмия хлорид.

\title{
QUANTITATIVE MORPHOLOGICAL ANALYSIS OF THE FEATURES REMODELING OF HEMOMICROCIRCULATORY BED OF THE TESTES AT THE ACTION ON THE BODY OF CADMIDIUM CHLORIDE
}

\author{
@M. S. Hnatiuk, S. O. Konovalenko, L. V. Tatarchuk \\ I. Horbachevsky Ternopil National Medical University
}

SUMMARY. Modern researchers point to the negative impact of harmful environmental factors on the reproductive function in men. Functional and structural changes of the hemomicrocirculatory bed, which is the first to respond to harmful factors of the environment, have not been sufficiently studied in the testes.

The aim - to conduct a morphometric analysis of the features remodeling of the hemomicrocirculatory bed of the testes when exposed to the body of cadmium chloride.

Material and Methods. Morphologically there were studied the testes of 60 white male rats, which were divided into two groups. Group 1 included 30 intact animals, group 2 - 30 rats who were subcutaneously administered cadmium chloride at a dose of $6 \mathrm{mg} / \mathrm{kg}$ for 4 weeks. Euthanasia of the animals was performed by bloodletting under thiopental anesthesia a month after the start of the experiment. The hemomicrocirculatory bed of the testes was studied by filling their vessels with a mascara-gelatin mixture that was injected through the abdominal aorta. Enlightened and histological preparations stained with hematoxylin-eosin were made from the testes. The diameters of arterioles, precapillary arterioles, hemocapillaries, postpillary venules, venules, and the density of microvessels of the left and right testes were determined morphometrically. Quantitative indicators were processed statistically.

Results. Prolonged exposure to the body of cadmium chloride led to marked changes in the quantitative morphological parameters of the vessels of the hemomicrocirculatory bed of testes compared with control. The diameter of the arterioles of the left testis in the simulated experimental conditions decreased by $19.2 \%(p<0.001)$, precapillary arterioles - by $23.3 \%$ ( $p<0.001)$, hemocapillaries - by $16.7 \%(p<0.001)$. The diameter of the postcapillary venules of the left testis thus increased by $32.7 \%$, venules - by $28.3 \%$ ( $p<0.001)$, and the density of the microvessel decreased by $30.0 \%$ $(p<0.001)$, which indicated a deterioration of his blood supply.

The degree of remodeling of the microvasculature in the right testis was less pronounced. The diameter of arterioles of the right testis decreased by $18.2 \%$, precapillary arterioles - by $22.6 \%$, and hemocapillaries - by $15.8 \%$ ( $p<0.001$ ). The diameter of the postcapillary venules of the right testis increased by $31.5 \%$, venules by $27.8 \%(p<0.001)$, and the density of microvessels decreased by $27.1 \%$ ( $p<0.001)$. Morphological changes in structures dominated the left testis.

Conclusion. Prolonged action on the body of cadmium chloride leads to a pronounced remodeling of the vessels of the hemomicrocirculatory bed of the testes, which is characterized by pronounced its narrowing of the bringing (arterioles, precapillary arterioles), metabolic (hemocapillaries) units, enlargement of postcapillary venules and venules, venous plethora, hypoxia, dystrophic, necrobiotic changes of cells and tissues, infiltrative and sclerotic processes that dominated the left testis.

KEY WORDS: testes; hemomicrocirculatory bed; morphometry; cadmium; chloride.

Отримано 4.05.2020 